Оригинальная статья / Original paper

\title{
Transcendentalism, Network Concepts and American Poetry
}

\author{
Nina F. Shcherbak ${ }^{\bowtie}$, Alena I. Gerus \\ Saint Petersburg State University, St Petersburg, Russia \\ $凶$ alpha-12@yandex.ru
}

\begin{abstract}
Introduction. The paper aims at describing the philosophy of transcendentalism as viewed by 19th century American philosopher Ralph Emerson, one of its founders and, above all, the direct application of this framework to the contemporary view of network concepts introduced as a state-of the art paradigm of cultural and social development, often viewed as directly applicable to the study of social processes as well as literary texts.
\end{abstract}

Methodology and sources. The chosen methodology includes the structural semantic study of Emerson's texts and the analysis of the view of contemporary philosophers of the language and literary critics on the network concept as a basis for state of the art social schemes and internet-communication principles, as well as literary texts analysis.

Results and discussion. The results of the research allow to hypothesize that the philosophy of transcendentalism which attempted to give a full-fledged representation of a harmonious and dynamic cosmic principle, seeing ways of moral purification and comprehension of the super-soul has similar principles with the works by outstanding poststructuralist or postmodern philosophers (like G. Deleuze) and is directly applicable to the study of contemporary literary texts if not social processes. These concepts allow to see the development of aesthetic paradigm (a vivid example being the development of the transcendental motive in poetry). One of the possible examples could be seen in the development of poetic paradigm with a) early romantic poetry concentrating on the poet's emotions, thus rendering the transcendental, with $b$ ) modernist writing which used language as a medium, when a poem became a means of expressing the transcendental, with c) poetry combining political views and the transcendental experience, with d) post-colonial poetry, with the transcendental being transferred from the sphere of "eternal" to the sphere of "everyday". Conclusion. American transcendentalism allows to see common patterns of development and innovation of cultural, literary, philosophical scene, characteristic of the contemporary aesthetic paradigm.

Keywords: transcendentalism, over-soul, self-reliance, network concepts, American poetry.

For citation: Shcherbak N. F., Gerus A. I. Transcendentalism, Network Concepts and American Poetry. DISCOURSE. 2020. Vol. 6, no. 1, pp. 106-120. DOI: 10.32603/2412-8562-2020-6-1-106-120

Conflict of interest. No conflicts of interest related to this publication were reported.

Received 03.12.2019; adopted after review 24.12.2019; published online 25.02.2020

\section{Философия трансцендентализма, сетевые концепты и американская поэзия}

\author{
Н. Ф. Щербак \\ Санкт-Петербургский государственный университет, Санкт-Петербург, Россия \\ 凶alpha-12@yandex.ru
}

(c) Shcherbak N. F., Gerus A. I., 2020

Контент доступен по лицензии Creative Commons Attribution 4.0 License.

This work is licensed under a Creative Commons Attribution 4.0 License. 
Введение. Целью статьи является критическое описание философии трансцендентализма, разработанной (среди прочих последователей) американским философом XIX в. Ральфом Эмерсоном, одним из ее основателей. Трансцендентализм впервые рассматривается как ключевая философская база, необходимая при анализе сетевых концептов, представленных как современная парадигма культуры и социального развития, необходимый инструмент для изучения литературных текстов и поэзии. Актуальность исследования обусловлена безусловной значимостью сетевых концептов (современной формы выражения трансцендентного) как основы современной литературной парадигмы.

Методология и источники. Выбранная методология включает в себя структурно-семантическое изучение текстов Эмерсона, анализ взглядов современных философов языка и литературоведов (Левина, Шобера, Фолсома) на сетевые концепты как основу современных социальных схем, принципов интернет-коммуникации, построения художественных и поэтических текстов. Анализ поэтических текстов проводится посредством сравнения основных моделей стихосложения, которые используются американскими поэтами в зависимости от эпохи и действующей эстетической парадигмы.

Результаты и обсуждение. Результаты исследования дают основание предположить, что философия трансцендентализма (которая ставила задачей дать представление о гармоничном и динамичном космическом принципе), позволяет увидеть аналогичные принципы, обозначенные в работах выдающихся современных философов (таких как Жиль Делез). Данные философские концепции оказываются наиболее продуктивными при анализе художественных и поэтических произведений, а также при выявлении особенностей развития художественной (эстетической парадигмы). В исследовании были обозначены четыре модели развития эстетической парадигмы при реализации мотива трансцендентного в поэзии: 1) романтическая поэзия концентрируется на эмоциях автора (его собственный трансцендентный модус); 2) в модернистской поэзии язык используется в качестве передачи основного смысла, поэзия становится средством выражения трансцендентного; 3) некоторые авторы комбинируют политические и трансцендентные мотивы; 4) в пост-колониальной поэзии мотив памяти создает дополнительную коннотацию трансцендентного, перенося его из сферы «вечности» в сферу «обыденного».

Заключение. Трансцендентализм позволяет увидеть общие закономерности развития и инноваций на социокультурной сцене, характерных для современной эстетической парадигмы. Основные положения пост-структуралисткой философской концепции (на примере Жиля Делеза) непосредственно применимы к изучению современных литературных текстов, а возможно, и социальных процессов.

Ключевые слова: трансцендентализм, сетевые концепты, вера в себя, сверхдуша, постмодернизм, американский романтизм.

Аля цитирования: Щербак Н. Ф., Герус А. И. Философия трансцендентализма, сетевые концепты и американская поэзия // ДИСКУРС. 2020. Т. 6, № 1. С. 106-120. DOI: 10.32603/2412-85622020-6-1-106-120

Конфликт интересов. О конфликте интересов, связанном с данной публикацией, не сообщалось.

Поступила 03.12.2019; принята после рецензирования 24.12.2019; опубликована онлайн 25.02.2019

Introduction. American transcendentalism was considered as a full-fledged representative of a harmonious and dynamic cosmic principle. The ideas of transcendentalism were expressed by R. Emerson H. D. Thoreau in the middle of the 19th century. Those who expressed transcendentalists' ideas believed that nature was endowed with inexhaustible spiritual strength. 
In approaching nature unspoiled by civilization, in its intuitive experience and unraveling its symbolic meanings, transcendentalists saw ways of moral purification and comprehension, in the words of Emerson, of the Over-soul. The main ideas of transcendentalism include social equality, spiritual self-improvement, closeness to nature, purifying a person of "vulgar-material" interests, intuitive understanding of the macrocosm through the microcosm. This view looks at people as individuals who are related to each other and are trying to get spiritual purification though intuitive feeling of the transcendental. Such an approach roughly corresponds to the ideas developed by G. Deleuze, the French poststructuralist, in that the basic foundation of metaphysics, human thought, cultural paradigm is not the tree like scheme or frame, yet should be viewed as a rhizome. The transcendental and network concepts paradigm (similar to that of the rhizome pattern) is viewed by contemporary researchers not only as characteristic of the American cultural tradition (as is argued by Schober) [1, p. 495-515] but is intrinsic to contemporary social and cultural paradigm, including that of communication and literary studies. One of the possible example could be seen in the development of poetic paradigm: (a) with early romantic poetry concentrating on the poet's emotions, thus rendering the transcendental; (b) with modernist writing which used language as a medium, thus expressing the transcendental, (c) the political and social view of the transcendental manifested in their writing by poets such as Walt Whitman, (d) the post-colonial poetry characterized by the author's position in the "found paradise", with the memory motif important and updated, which creates an additional connotation of the transcendental, transferring it from the sphere of "eternal" to the sphere of "everyday".

Methodology and sources. The chosen methodology includes the structural semantic study of Emerson's texts and the analysis of the view of contemporary philosophers on the language, their opinion on the network concept as a basis for state of the art social schemes and internetcommunication principles, as well as literary texts analysis.

A century after his death, Ralph Waldo Emerson still seems more like an icon than a classic. Emerson is the author of essays such as "Self-Reliance" (1941), such deep experiences, immersions in pure mysticism as the work "Over-soul", which is believed to have had a huge impact on the minds of American writers. Poet Walt Whitman (1819-1992) (an innovator of verse, who was one of the first to "break" the poetic rules, bringing the poetry closer to the rhythm of the psalms, the poet who "preached democracy") called Emerson "the actual discoverer", though some scholars fiercely criticized Emerson's deeply idealistic views. Nevertheless, his works appear in the beauty and uniqueness of his mind, in the boundless affirmation of "the thinker of once almost crushing idealism" [2, p. 7].

The attempt to compare psychology and theology in relation to Emerson's work seems interesting enough. Despite the apparent differences, similar motives and intersections in the works of Emerson and the classics of psychology quite a lot. The researcher E. Edinger writes about Emerson: "From the first day of my acquaintance with analytical psychology, I was struck by the numerous Parallels between Emerson's intuitive insights and Jung's experiential psychology. I knew and loved Emerson long before I heard of young's existence. I accepted with all my heart his sonorous phrases: "Trust yourself. Every heart vibrates to the rhythm of this steel string"; "Envy is born of ignorance... imitation is suicide"; "He who wants to be a man must be a nonconformist ... nothing is more sacred than the inviolability of his own mind" $<\ldots>$ He called himself a "naturalist of the soul", and this figurative term accurately describes him. In addition, Jung was well acquainted with Emerson's works and referred to him several times in his writings" [3, p. 1-10]. 
Summing up his work, Emerson pointed out that it is dedicated to the "infinity of the private man" [4, p. 5]. Emerson is particularly explicit in building a bridge between nature and culture in his early essay "Nature" (even more emphatically than does the philosopher Thoreau). Emerson begins the essay by describing the reproductive dynamics of natural growth cycles: nature in its service to man is not only a material, but also a process and a result. All parts continuously work in a predetermined cycle for human use. The wind carries the seed; the sun evaporates the sea; the wind carries the steam into the field; the ice on the other side of the planet condenses the rain; the rain nourishes the plant; the plant feeds the animal; and thus the infinite appeals of divine mercy nourish man [2, p. 20]. Nature and the Soul are the two components of the Universe). By nature, Emerson means the Fichte-Schelling "not-I" (the not me), which incorporates the entire realm of the conceivable, including art, other people, and even one's own body. However, the human soul is not opposed to Nature. It is a part of God, through which the "currents of Universal Being" pass.

In his essay "Circles" (1841) Emerson explains the periods of human development (the idea of the circle captured by the subsequent explanation of Nietzsche's ideas, which, among others, including the notion of the constant (eternal), as could be naturally observed in the phenomenon of a "comet" [2, p. 250]. Emerson writes that a person should: "just experiment, being an endless seeker with no past behind him". "I'm just experimenting" is how Emerson expressively described his gift for communicating with himself in "Circles". "Circles, then, is one of the finest meditations, in the spirit of F. Nietzsche and Thomas Carlyle". Here are a few more quotes: "The key to every man is his thought"; "Conversation is a game of circles"; "Human life is a selfdeveloping circle, which, forming a subtle ring, rushes out to new and larger circles, and this is an endless process"; "There is no outside, no enclosing wall, no circumference for us".

The natural world may be conceived of as a system of concentric circles, and we now and then detect in nature slight dislocations, which apprize us that this surface on which we now stand is not fixed, but sliding. These manifold tenacious qualities, this chemistry and vegetation, these metals and animals, which seem to stand there for their own sake, are means and methods only, - are words of God, and as fugitive as other words" [2, p. 252].

The essay "Circles" is an appeal to Emerson's listeners and readers to think cosmically. We must see the circle formed by the eye and the "horizon that is the form" as symbols of a universe that exists not only physically for our perception, our science, but also metaphysically and religiously. We can say that the universe exists only because the human soul reflects it, knows about it, because the soul carries "divine waves". We know where we are, here and now, because of the sense of infinity that we possess - for which we alone are the key. The essence of human existence is not satisfaction, but the attainment of correct perception. According to Emerson, the only possible purpose of such knowledge is to "feel God". We do not need churches or traditions to do this, only our own free, fearless, independent and joyful through our recognition, we are the divine essence, which is inherent in the beauty and repetition of creation. In fact, we are the "soul", nothing but the soul, and the soul is what allows us to be closer to the higher circle, which is the universe of God.

One of Emerson's most striking essays is "Self-reliance" (1841) [2, p. 390]. As the Russian poet Joseph Brodsky once wrote, "any career of a writer begins with a personal search for Holiness, self-improvement. Often, however, the writer realizes that he writes with his pen much more than 
his soul can say, this becomes the main function of writing: to combine the flight of the pen and the motives of the heart". Emerson, similarly, looks for himself in the essay "Self-Reliance": "Insist on yourself; never imitate. Your own gift you can present every moment with the cumulative force of a whole life's cultivation; but of the adopted talent of another, you have only an extemporaneous, half possession. That which each can do best, none but his Maker can teach him. No man yet knows what it is, nor can, till that person has exhibited it" [2, p. 390].

Emerson's strategy in writing is similar to that of the fire. In "Over-soul" (1841), Emerson is at the top of his own spiritual identity, speaks of boundless freedom and ideal faith. "Super-soul" is no longer the work of a preacher about self-belief, it is the study of a mystic, evidence of how the writer received his own revelations about the universal soul in the post-Christian era. There is a fusion of ideas, a myriad of motives. The essay mentions the philosophers and writers Spinoza, Kant, Coleridge, Locke, Pope, Homer, Chaucer, the rulers Charles the Second, James the First, Shakespearian famous characters Hamlet and King Lear, demonstrating the divine presence in each of the representatives of cultural and historical realities that enter human life by divine will [2, p. 400].

\section{Results and Discussion.}

Transcendentalism and network concepts. Modern American researchers have repeatedly noted that in Emerson's philosophy lies the idea of networks, so characteristic of American culture, to some extent determining its state and position in the 19th century, reflecting its trends for the modern era. To some extent, this is in harmony with the concept of the rhizome of the French poststructuralist philosopher Gilles Deleuze used to account for contemporary cultural and aesthetic paradigm of the 20th century and postmodernism.

It is obvious that the notion of a network underlying transcendentalist discourses is more problematic than the supposedly clear dualism between the material and the immaterial. Rather, these networks intersect and form unexpected interfaces. Linked to both material and ideal notions of interconnectedness, the network reconciles and transcends oppositional values in the writings of Emerson and Thoreau. While the railway and the telegraph are partly connected with the illegal invasion of the natural order of things, their unifying potentials are embraced in connection with a common desire to connect. The idea of transcending spatial boundaries is perceived as something that promotes human well-being and as something that puts individual prosperity at risk.

As noted by Schober, while the postmodern view of the web as a fundamentally dehumanizing, disembodied technology, beyond human control and understanding, is already looming in the idea of a network, the potential of networks to promote personal, social, and political unity is seen equally [1, p. 500]. For many nineteenth-century authors, including Emerson, the concept of the web, inspired by new technological developments, is adapted to intangible contexts, often metaphorically. Network technologies are seen as offering epistemological potential to offer new thinking models [1, p. 502]. In addition to commenting on the immediate material environment, network image serves to create visions of new aesthetic and cultural forms arising from transformed concepts of interconnected spatiality. Transcendentalist conceptions of the web as a metaphor figure in relation, but not necessarily in opposition, to its material consequences, bears in mind the respected values of spiritual and metaphysical interconnectedness. Emerson's concept, in fact, is indicative of such an intangible network that is very compatible and closely related to the idea of community. His idea of an "imaginary 
community" is based on the idea of a form of virtual interconnection between people who are connected to each other through spiritual connections rather than through emotional or conceptual views and beliefs. Emerson [2, p. 155] distinguishes between exclusively material and ideal networks of community, between social conformity and the "virtue of solitude". The very ability to be completely free from external control and influence is considered a key value for a personal character. However, self-confidence is not seen as a contradiction, but rather as a condition for achieving spiritual interconnectedness. In Emerson's essay "Worship" (1860), the concept of a network takes on a spiritual connotation. Emerson here postulates that human existence has an inherently spiritual predisposition, arguing that "relationships and connections are not somewhere and sometimes, but everywhere and always; there is no difference, no exceptions, no anomalies but a method and an even net; and what comes out is what has been inserted" [1, p. 493-505]. This hidden net, however, is not destiny, but "inspiration" associated with and arising from the presence of the Over-soul. Emerson regards the Over-soul as the "great nature" in which the separate being of each person is contained and connected with all the others: "We live in succession, in division, in parts, in particles. Meantime within man is the soul of the whole; the wise silence; the universal beauty, to which every part and particle is equally related, the eternal ONE" [2, p. 175].

The Over-soul itself can be understood as an invisible web that binds people together, giving rise to what Folsom [5, p. 266] called the key to transcendentalism: "Transcendentalism valued self-confidence and independent action", but it "valued these qualities, paradoxically, in the knowledge that they exist under Central control, the Over-soul". In describing Emerson's concept of the Over-soul as something spiritual that "flows through all creation," Ph. Gura [6, c. 94] emphasizes the process of the flow of energy that defines this spiritual process.

One of the seeming paradoxes of Emerson's often misunderstood concept [particularly his ideas of Self-reliance (1841)], [1, p. 505] is that Emerson's writing contains a basic conflict between a certain belief in "connectedness" between the individual and the universe and the "transcendentalist dislike of all forms of association". The supposed opposition between these two forms of relationship, spiritual-ideal, on the one hand, and material-social, on the other, are actually two sides of the same coin.

Emerson does not postulate self-liberation from any connection. Self-reliance gave rise to "a discourse that fostered U. S. exceptionalism based on self-interest" [1, p. 496]. Self-reliance does not mean absolute independence, but submission to the power and influence of the Over-soul. "That's right, every person is a channel through which the sky flows" [2, p. 275]. Christopher Newfield calls Emerson's balanced individualism central to the emergence of American liberalism, which contrary to popular belief, contributes to "the consolidation of freedom through the loss of both private and public control" [7, p. 5]. Although Newfield's reading of Emerson is politically defined, placing individualism on the edge of self and community suggests an underlying transcendent connection.

As J. Levin (1999) suggests, Emerson's personality is a tightly organized network of both internal and external connections that constantly interact with each other. Linking Emerson's transcendentalism to the pragmatic epistemology, Levin argues that the relationship between self and divine intuition, or genius, must be understood as deeply interactive processes: "Man and his permanent genius exist for Emerson in a paradoxical relationship of interdependence and absolute incongruity. The power of genius ultimately does not belong to a stable, consistent, rational agent, but 
rather comes from other forces that precede and include that agent and his Agency. The more a rational agent controls himself, the less this self will exercise these powers. Ironically, the Self remains the place where forces circulate, although it is by no means the source of that force" [8, p. 28].

For Levin, the apparent paradox of self-confidence and social interconnectedness disappears if we start from the fundamental instability of the Self as a mode within the network of external influences. Along these lines, the self in its independence is not a fixed entity, but is essentially a dynamic process, or rather a place, in which spiritual and universal currents converge. At the same time, this convergence means that the self is not completely fragmented, but rather represents a certain coherence of relationships. The self is then stable, flexible, diverse, and one. In Emerson's writings, epistemology is often associated with the concept of the visual, intriguingly also the preferred conceptual area for representing networks. For Emerson, this serves as a way to link literal meaning to metaphor, thereby creating an inherent link between material and ideal that also works at the level of rhetoric.

Transcendentalism, the concept of rhizome, communication and literary studies.

Emerson's views allow to, firstly, draw parallels between his writings and works of contemporary poststructuralist philosophers like G. Deleuze who form the foundation of the aesthetic paradigm. Secondly, Emerson's writing is directly applicable to the analysis of poetic and literary works, as well as contemporary communication and internet communication patterns.

Firstly, transcendentalism is very similar to that of G. Deleuze who maintains in his later works that the connectedness between elements in the world is characterized by decentralization. In the case of human being and their connectedness, the process includes the blurring of all the pre-conceived habits of one's consciousness that allows us to think that we are individuals who are independent. Deleuze refer to schizoid kind of reality that allows to "approach a beating heart of reality to the point of its intensity, identical to the construction and production of reality" [9].

From here Deleuze develops the idea of the organism deterritorialization of the organism, following the flight movement that allows for a full disconnection. From here rises the imperative for de-stratification of the situation: if creations are renewed, the created strata could interrupt the lines. "Strata" is what isolates us from the consistent surfaces, where there is not regime of signs, where the line of flights allows to activate potential positive force and allows for positive outcome and de-territorialization [10]. That is above all, the declaration and strive for the transcendental.

Secondly, Ralph Emerson's writings are applicable to the study of literary texts. The philosopher writes the essay "Poet" in which he anticipating the era of modernism and post-modernism, periods in which criticism will become a work of art, prose will become poetry, and poetry will turn into music. According to Emerson, the mask of the poet is the mask of the actor who is involved in the process of creating a work of art, the role of which for the 20th and 21 st centuries becomes decisive. The person speaking and playing replaces any of the earlier existing paradigms, gaining transcendence through freedom of speech (discussed at length in part 4 of this article). Emerson wins the sympathy of readers in Germany, has an influence on F. Nietzsche. In France and Belgium, he does not become so popular, although his work will be interested in M. Maeterlinck, A. Bergson and S. Baudelaire. In Russia, the writer made a strong impression on Leo Tolstoy and a number of other writers, who, however, often saw in his work only the revelations of a religious figure.

I would argue that in the field of contemporary linguistics and communication one of the main principles is that communication process does not consider what is directly said in a given 
communicative situation, but what the speaker implies, what strategies the speaker uses in the communication process, whether there are communication failures when trying to transmit a message. Pragmatics and social theories of language have expanded the range of communicative tasks. Rapid development of computer technology allows us to talk about cyber pragmatics [11, p. 13], studies of those codes and rules that are established in the process of Internet communication. In this case, it becomes important that "information in the cyber context is limited by the interpretative requirements of the stimulus, whether it be a picture, a statement or a video, and it is dynamic, being in the process of constant evolution" [ibid., p. 15]. A participant in a communicative situation on the Internet can play an increasing number of roles and influence a larger number of social groups. Studies in the field of Internet communication show that when communicating, there is no substitution of identity, yet the identity becomes more "fragmented" and "diverse" [12, p. 37], which leads to an endless range of possible ways of communication, the use of various means of communication, the constant change of codes, the application of additional strategies to maintain the conversation. The recognition of such complexity is in the best possible harmony with the recognition of differences between people, the maintenance of any form of development of personal and interpersonal qualities.

\section{Transcendentalism and American poetry.}

The results of the research showed that the transcendental motive in American poetry can manifest itself in various forms and through various means. In the process of analyzing the research results, four main models for the implementation of the transcendental were found. Firstly, a poet on behalf of a lyrical hero can convey his own feelings and emotions (this occurs in the poetry of Romanticism). Secondly, the poet can concentrate the reader's attention not on the described personal experiences, but on the linguistic means that structure the reader's perception (as, for example, in the poetry of T. S. Eliot). The poem in this case becomes a means of expressing the transcendental, and the close attention to the author completely changes the canons of versification. Thirdly, a number of poetic examples (Whitman's poetry) demonstrate cases of the social interpretation of the transcendental, a special case of which is the realization of the concept of "network", the actualization of the interconnections of man, the world around him and the divine, which underlie the philosophy of transcendentalism (represented by Emerson and Thoreau). Fourthly, post-colonial poetry is characterized by the author's location in the position of "newfound paradise", and the memory motif is often updated, which creates an additional connotation of the transcendental, transferring it from the sphere of "eternal" to the sphere of "ordinary".

Firstly, the poetry of the American poet Edgar Allan Poe is a clear example of such a personal generation of poetry based on his own experiences, an example of his own romantic experience, which is presented to the reader by the creator of the poem. The main motives are longing, loneliness, disappointment, death, according to Y. Kovalev, a famous biographer and critic of E. Poe's creativity, this is "a traditional set of European romantic lyric poetry of the Byron sense", "it recorded a certain mentality and state of mind generated by life experience of a poet", and "experience itself, as a rule, was not subject to image, it remained outside the text: lyric poetry was distinguished by some abstractness, romantic lyrics were doubly distinguished by it" [13, p. 76]. An incredible surge of emotion "Annabel Lee”, a poem written by E. Poe shortly before his death (the one that Nabokov uses to create the famous "Lolita"): 
It was many and many a year ago,

In a kingdom by the sea,

That a maiden there lived whom you may know

By the name of Annabel Lee;

And this maiden she lived with no other thought

That to love and be loved by me.

In this poem, the focus is on the personal experiences of the lyrical hero, the motives of the "impossible", the motives of "loss" and "gain", the impossibility of "merging" and at the same time - "eternal harmony", "life and death" (in the text "and this maiden lived with no other thought than to love and be loved by me"), but at the same time the motive of "wedding", which is one of the fundamental in the poem, can be understood only in the categories of "death" or "sleep" (realized in the text my darling, my life and my bride, in her sepulcher there by the sea, in her tomb by the side of the sea).

The second type of a model of how to express the transcendental is linked to the ideas of modernism and is fundamentally different from that of the Romanic era. One possible example of the poetics of modernism could be an idea related to "Chinese writing", an ideogram, an idea discussed by Pound and then Ernest Fenollosa in the work "Chinese writing as a language of poetry" (1919) [15]. This concept shows the possibility of considering poetry from the point of view of rational and critical doctrine. Fenollosa believes that Chinese writing has the potential not only to cause "thoughts with pictures or images" in consciousness, using signs, as is the case with any writing, but that these "ideograms" carry out their task "livelier and more concrete", since they do not abstract either to what is "outside of representation", to nothing, what is not in the text. The Romantic poets, on the contrary, have referenced to an infinite indefinite set, while the ideogram or icon provides our attention with "instant concrete form" presented to the reader [ibid., p. 140]. Fenollosa believed that "reading Chinese" and the modus of images suggests that "we do not lose mental possibilities", trying to choose the necessary value or interpretive option, on the contrary, we "observe how the reading process follows its destiny" [15].

In this sense, the ideas of the Russian theologian Pavel Florensky about the iconicity of the sign, its transcendence, are very relevant. In his essay "Is Rublev's Trinity Visible to non-believers?" I. Kish refers to the text of the "Iconostasis" by Pavel Florensky and analyzes the properties of an iconic image to actually acquire the properties of the transcendental, that is, to actually be not holy or otherworldly images, but to be them. "P. Florensky suggests that the ability to see an icon by itself, automatically, is not given to us: the ability of spiritual vision by the icon itself awakens in consciousness". The icon does not just "affirm that there is such a perception, that is, that we can generally perceive the invisible, but makes us feel our own experience of this kind" [16, p. 102]. According to Kish, the work of Pavel Florensky answers questions regarding the perception of the icon, the idea of the structure of the image on the icon, the idea of the nature of the icon sign. The similarity of the sounding of the terms "iconic sign" and "iconic sign" is not accidental. An iconic sign is an icon whose meaning is to be otherworldly, while an iconic or iconic sign is a sign that, according to the terminology of linguist Charles Pearce, resembles a concept or meaning actualized through this sign. Pavel Florensky writes that the icon painter does not repeat the visible highland world, but fixes with the help of paints the "invisible world that appears before itself". 
So, modernist writers of the turn of the century considered themselves to be standing at the end of a certain period, marking a new path. Ezra Pound's called for "renewal" which was an exclamation and a call among the representatives of the art scene. The appeal meant "renewing the old" and "breaking with it" at the same time. Eliot considers himself to be the vector of the art development (which is referred to as "modernism") as opposed to the romantic humanism of Victorian England. In his essay on Arnold, for example, Eliot claims that Arnold "draws attention precisely to the poet's feelings, and not to poetry itself' [17, p. 115].

In 1909, Eliot still uses traditional rhymed stanzas, but the mood is special, as Perloff notes $[18$, p. 7-43], as many referents are too blurry:

This charm of vacant lots!

The helpless fields that lie

Sinister, sterile and blind -

Entreat the eye and rack the mind,

Demand your pity.

With ashes and tins in piles,

Shattered bricks and tiles

And the débris of a city.

(Eliot T. S. Second Caprice in North Cambridge, 1909)

In this poem, the vocalizations are highlighted most vividly: the game like echo of 1consonants creates a special mood in the description of the landscape, as if the picture of the city is compressed and unclenched, while the syllables on the first and fourth stanzas are short, on the second and third they are - long, which again - creates a certain non-linearity, some "raggedness", but at the same time the smoothness of the verse (pity, tiles, piles, city).

What poetry ideas are relevant to understanding Eliot's work? "There are no thoughts outside the language. There is no natural sound in the poem. The basis of writing is creation, the design process", writes Bernstein [19, p. 49]. Davidson points out similar power of linguistic means, but above all mentions the fact that the poet plays a certain social role, which is not necessarily political: "Unlike political poetry of the last twenty years, the functioning of the language does not base its analysis of authority or legitimation on politics itself $<\ldots>$ Moreover, emphasizing the abstract features of speech, rather than the authenticity of the expressive moment, the poet recognizes the importance and indispensable power of utterance in the process of social communication" [20, p. 70]. Heinan supports a similar idea: "By focusing on the written implementation of a word, the poem draws attention to the complexity of the construction process" [21, p. 329].

The basic concept for each of Eliot's poems is constructivism - the understanding that language is not a means or container for thoughts and feelings, it is itself a springboard for generating meaning. When Bernstein claims that there are no thoughts outside the language, he reproduces Wittgenstein's famous aphorism described in the Logical and Philosophical Treatise: "The Limitations of My Language - the Limitations of My World", or the idea expressed earlier: "Do not forget that poetry is designed to construct" [16].

In "Metaphysical poets" [22, p. 207] Eliot writes that "when the poet's consciousness has taken the proper condition for further work, it resembles an amalgam, an amalgam pattern of experience, an ordinary person's experience is chaotic, disordered fragmentation, he falls in love, 
reads Spinoza, there is no connection between these two types of experience "but with the sounds of a typewriter beating on the keys, or the smell of food, in the poet's mind, these options of experience always form new possibilities of choice". The poetics of modernism, therefore, are trying to build their own system of "new whole". Art for modernists and for Eliot, in particular, is a form of transformation in which the difference between reality and art is enormous. At the same time, S. Mascaffery is right in defining this tendency as "concentration on the concreteness of the sign, and not on the transcendence of the referent" [23, p. 19], which rather brings such poetry closer to Joyce's Finnegan's Wake, and not at all to other works.

"The limitations of the language are the impossibility to convey any fact conveyed in this sentence without having to repeat this sentence", writes Wittgenstein [24, p. 5]. If we replace the word in Eliot's line with random synonyms like "troubled" or "anxious", Perloff comments, then "st" will lose its sound or repetition, or the mirror interaction of "le" with "el", as in "shells-hotels" [16]. Thus, echo elements (restless, sawdust, oyster), repetitions of "rest" in "restless", "restaurants" will be lost. Similarly, you shouldn't lose the echo in some lines in which there is a repetition of the word "night" (in the text "Of restless nights in one-night hotels") [16]. Obviously, Eliot wrote at a time when poetry did not exist in a new form which he himself was the forerunner and the founder of.

Thirdly, the poetry of $\mathrm{W}$. Whitman is one more example of the realization of the transcendental. Like every American, according to R. Schober, Whitman's poetry is based on the idea of combining the material and the ideal, that is, following Emerson, combines the possibilities of the real world and the transcendental properties of man, words and poetry. Whitman is a pastor of democracy who writes at the same time about the social (entrusting his verses to the many different voices that write them), and at the same time arranges them like a prayer. Schober postulates the idea of a network concept [1], a rhizomatic (according to Deleuze) education, which equally conveys modern American self-consciousness (the idea of self-reliance and Over-soul) and its material embodiment (railways, "network concepts", as a metaphor for the organization of American society). Whitman's poetry, therefore, is a continuation of the same famous philosophy of Emerson, that is, it tells about the transformation of society, which leaves room for both social and individual development of intuition and feeling. If some of Whitman's poems, such as "Noiseless Patient Spider", or "Passage to India" refer directly to the concept of the "web", in other works the interconnection of incompatible concepts from the life of American society, as well as the idea of universal unity, is implicitly expressed as, for example, in Whitman's poem, "Starting from Paumanok". The poem is an example of the transcendentalist idea of the "network", extending this idea simultaneously to the personal, social, national spheres, connecting it with all aspects of being. The poem creates the utopian illusion of the United States as a network that is outside the division of the material world and the ideal world, putting the "network" on a concrete level and at the same time socio-political. The poem describes the various stages of the life of a lyrical hero. The lyrical "I" is the embodiment of a developing individual who moves from one geographical point of the USA to another (from Manhattan to the southern savannahs and forests of Dakotta). Various locations, realized as the stops of the hero, are not only the places he visits, from a metaphorical point of view, these points are the starting points of a new stage in the development of the hero, his personal experience (he simply lives, then becomes a soldier, then "is in deep thought)" [25, lines 40-172]. All this diverse experience leads the speaker to conclusions about life: victory, unity, faith, identity, time. All these concepts confirm that the hero unites the 
history of natural and technological transformations, universal laws, space and objects of the material world with his life path and experiences. An important aspect of Whitman's work is the meta-text function of his poetry, which demonstrates how the act of writing a letter implements all possible spiritual and spiritual experiences, thus combining spiritual formation and material embodiment of this formation in the traditions of transcendentalism.

Fourthly, postmodernism is indeed a slightly different phenomenon in relation to the transcendental, yet it apparently could be viewed as one of its further and later manifestations. According to I. Smirnov, the postmodern author is a kind of a symbiotic child who writes while in paradise. This is a slightly different, poststructuralist interpretation of the famous Frege triangle: the sign enters into an endless process of meaning, and, from the point of view of psychoanalysis, Igor Smirnov defines symbiosis as such: "A symbiotic infant is subjective. His behavior is symptomatic. The gestures he makes suggest that he would like to imitate his power source". Smirnov continues: "For a symbiotic child, subjective and objective are both equivalent to it (since it is auto-reflexive, self-alienating) and transcendental (since it considers the mother to be equivalent to it) <... Earthly paradise (the image of symbiosis for most non-symbiotic subjects, which idealize the beginning of what they have at their disposal - the starting point of their subjectivity) is for the postmodernist the place where he sees the world, and not where he seeks to get out of the world (like Adam the sadoavant-garde). The postmodernist thinks like Adam, but not about Adam; he does not notice that Eden is leading his speech; he does not distinguish between sextuple and otherworldly $<\ldots>$ The symbiotic with its auto-reflexion has no other position in the world except meta-position $<\ldots>$ a story that the symbiotic does not control only comes to him as a dream" [26, p. 317-331].

Such a view is very characteristic of post-modern poetry, especially in its post-colonial manifestation:

Presiding over a formica counter, plastic Mother and Child magnetized to the top of an ancient register, the heady mix of smells from the open bins of dried codfish, the green plantains hanging in stalks like votive offerings, she is the Patroness of Exiles.

One could see in this poetry the connection of the motive of faith and church (actualized in the description of the Saint Mary) and its juxtaposition with everyday object (heady mix of smells form the open bins), which brings together the sublime and the trivial allowing to have an ironic view of the scene, combining the traditional scheme of God-like characters and the contemporary rejection of the sublime.

Conclusion. Transcendentalism in the face of the teachings of Emerson allows to see common patterns in the development of the state of the art social and cultural scene characteristic of the contemporary aesthetic paradigm. One of the possible examples could be seen in the development of network concepts thus expanding the understanding of the aesthetic paradigm. This view is very similar to the rhizome concept introduced by G. Deleuze, in many ways developing in line with contemporary communication studies. Poetic paradigm development (the example being the 
American poetry) could be seen as manifested in four models. The first one includes early romantic poetry concentrating on the poet's emotions, thus rendering the transcendental. Secondly, with modernist writing which used language as a medium, when a poem became a means of expressing the transcendental. The third model allows to see poetry as a social and political means, yet linking it to the transcendental as one could see in the works by W. Whitman. The post-colonial poetry is characterized by the author's location in the topos of the "found paradise" and accounts for the fourth model, with the memory motif important and updated, creating an additional connotation of the transcendental, transferring it from the sphere of "eternal" to the sphere of "everyday".

\section{REFERENCES}

1. Schober, R. (2014), “Transcending Boundaries: The Network Concept in Nineteenth-Century American Philosophy and Literature", American Literature, vol. 86, no. 3, pp. 493-521. DOI: https://doi.org/10.1215/00029831-2717389.

2. Emerson, R.W. (1982), Selected Essays, Penguin, N.Y., USA.

3. Ral'f Uoldo Emerson: naturalist dushi [Emerson: naturalist of the soul], Transl. by Edinger, E.R. available at: https://castalia.ru/perewody/yungiantsy-blizhnij-krug/2943-edvard-edinger-ralf-uoldoemerson-naturalist-dushi.html (accessed 20.11.2019).

4. Kazin, A. (1979), "Introduction", The essays of Ralph Waldo Emerson, Harvard Univ. Press, Cambridge, UK, pp. VII-XIX.

5. Folsom, E. (2010), "Transcendental Poetics: Emerson, Higginson, and the Rise of Whitman and Dickinson", The Oxford Handbook of Transcendentalism, in Petrulionis, S.H., Walls, L.D., and Myerson, J. (ed.), Oxford Univ. Press, Oxford, UK, pp. 263-290. DOI: https://dx.doi.org/10.1093/oxfordhb/ 9780195331035.013.0019.

6. Gura, P.F. (2008), American Transcendentalism: A History, Hill and Wang, N.Y., USA.

7. Newfield, C. (1996), The Emerson Effect: Individualism and Submission in America, Univ. of Chicago Press, Chicago, USA.

8. Levin, J. (1999), The Poetics of Transition: Emerson, Pragmatism, and American Literary Modernism, Duke Univ. Press Books, Durham, USA.

9. Deleuze, G. and Guattari, F. (1972), Anti-OEdipus, Trans. by Hurley, R., Seem, M. and Lane, H.R., Continuum, London, UK.

10. Deleuze, G. and Guattari, F. (2005), A thousand plateaus: capitalism and schizophrenia, Transl. by Massumi, B., Univ. of Minnesota Press, Minneapolis, USA.

11. Yus, F. (2011), Cyberpragmatics. Internet-mediated communication in context, John Benjamins Publishing Company, Amsterdam, ND. DOI: https://doi.org/10.1075/pbns.213.

12. Turkle, Sh. (1994), "Constructions and reconstructions of self in virtual reality: playing in the MUDs", Mind, culture and activity, vol. 1, no. 3, pp. 158-167.

13. Kovalev, Yu.V. (1984), Edgar Allan Po. Novellist i poet [Edgar Allan Poe. Novelist and poet], Khudozhestvennaya Literatura, Leningrad, USSR.

14. Poe, E.A. Annabel Lee, available at: https://www.tania-soleil.com/edgar-allan-poe-annabel-lee/ (accessed 01.07.2019).

15. Fenollosa, E. (1951), The Chinese Written character as a Medium of poetry, Transl. by Pound, Ez., Square Dollar Series, Washington, USA.

16. Hagemeister, M. and Kauchtschischwili, N. (eds.), P. A. Florenskij i kul'tura ego vremeni [P. A. Florensky and the culture of his time], Blaue Hörner, Marburg, DEU. 1995.

17. Eliot, T.S. (1953), Selected essays, Faber and Faber, London, UK.

18. Perloff, M. (2002), 21st Century Modernism. The "New" Poetics, Blackwell Publishers, Oxford, UK.

19. Bernstein, Ch. (1986), Content's Dream Essays. 1975-84, Sun and Moon, L.A., USA.

20. Davidson, M. (1998), "From Act to Speech act", in Beach, Ch. (ed.), Artifice and Indeterminacy: An Anthology of New poetics, Univ. Alabama Press, Tuscaloosa, Alabama and London, USA. 
21. Heinan, L. (2000), The language of inquiry, Univ. of California Press, Berkeley, USA, pp. 296-317.

22. Kermode, Fr. (ed.), (1975), Selected Prose of T. S. Eliot, Harcourt Brace, N.Y., USA.

23. McCaffery, S. (1996), The cheat of words, ECW Press, Toronto, USA.

24. Wittgenstein, L. (1980), Culture and value, Transl. by Winch, P., in Wright, G.H. and Nyman, H. (ed.), Univ. of Chicago Press, Chicago, USA.

25. Whitman, W. (2005), "Starting from Paumanok", Leaves of Grass, New American Library, N.Y., USA, pp. 11-22.

26. Smirnov, I.P. (1994), Psikhodiakhronologika. Psikhoistoriya russkoi literatury ot romantizma do nashikh dnei [Psychodiacronology. The psychohistory of Russian literature from romanticism to the present day], Novoe literaturnoe obozrenie, Moscow, RUS.

27. Judith Cofer Ortiz, The Latin Deli: An Ars Poetica. Available at: https://www.slideserve.com/homer/ presiding-over-a-formica-counter-plastic-mother-and-child-magnetized (accessed 19.12.2019).

\section{Information about the authors.}

Nina F. Shcherbak - Can. Sci. (Linguistics) (2015), MA in English language teaching (Lancaster, UK), Associate Professor at the Department of English Philology and Cultural Studies, Saint Petersburg State University, 11 University emb., St Petersburg 199034, Russia. The author of 150 scientific publications, monographs and books. Area of expertise: narratology, pragmatics, cognitive linguistics, psycholinguistics, literary studies. ORCID: https://orcid.org/0000-0001-8725-9717. E-mail: alpha-12@yandex.ru

Alena I. Gerus - student (2 year, master) at the Department of English Philology and Cultural Studies, Saint Petersburg State University, 11 University emb., St Petersburg 199034, Russia. The author of several scientific publications. Area of expertise: cognitive linguistics, narratology, pragmatics. E-mail: aleneguere@gmail.com

\section{СПИСОК ЛИТЕРАТУРЫ}

1. Schober R. Network concepts. Transcending Boundaries: The Network Concept in NineteenthCentury American Philosophy and Literature // American Literature. 2014. Vol. 86, № 3. DOI: https://doi.org/10.1215/00029831-2717389.

2. Emerson R. W. Selected Essays. N.Y.: Penguin, 1982.

3. Ральф Уолдо Эмерсон: натуралист души / пер. Э. Эдингера. URL: https://castalia.ru/perewody/ yungiantsy-blizhnij-krug/2943-edvard-edinger-ralf-uoldo-emerson-naturalist-dushi.html (дата обращения: 20.11.2019).

4. Kazin A. Introduction // The essays of Ralph Waldo Emerson. Cambridge: Harvard Univ. Press, 1979. P. VII-XIX.

5. Folsom E. Transcendental Poetics: Emerson, Higginson, and the Rise of Whitman and Dickinson // The Oxford Handbook of Transcendentalism / S. H. Petrulionis, L. D. Walls, J. Myerson (ed.), Oxford: Oxford Univ. Press, 2010. P. 263-290. DOI: https://dx.doi.org/10.1093/oxfordhb/9780195331035.013.0019.

6. Gura P. F. American Transcendentalism: A History. N.Y.: Hill and Wang, 2008.

7. Newfield C. The Emerson Effect: Individualism and Submission in America. Chicago: Univ. of Chicago Press, 1996.

8. Levin J. The Poetics of Transition: Emerson, Pragmatism, and American Literary Modernism. Durham: Duke Univ. Press Books, 1999.

9. Deleuze G., Guattari F. Anti-OEdipus / transl. by R. Hurley, M. Seem, H. R. Lane. London: Continuum, 1972.

10. Deleuze G., Guattari F. A thousand plateaus: capitalism and schizophrenia / transl. by B. Massumi. Minneapolis: Univ. of Minnesota Press, 2005.

11. Yus F. Cyberpragmatics. Internet-mediated communication in context. Amsterdam: John Benjamins Publishing Company, 2011. DOI: https://doi.org/10.1075/pbns.213. 
12. Turkle Sh. Constructions and reconstructions of self in virtual reality: playing in the MUDs // Mind, culture and activity, 1994. Vol. 1. № 3. P. 158-167.

13. Ковалев Ю. В. Эдгар Аллан По. Новеллист и поэт. Л.: Худ. лит., 1984.

14. Poe E. A. Annabel Lee. URL: https://www.tania-soleil.com/edgar-allan-poe-annabel-lee/ (дата обращения: 01.07.2019).

15. Fenollosa E. The Chinese Written character as a Medium of poetry / transl. by Ez. Pound, Washington: Square Dollar Series, 1951.

16. П. А. Флоренский и культура его времени / под ред. М. Хагемайстера, Н. Каухчишвили. Marburg: Blaue Hörner, 1995.

17. Eliot T. S. Selected essays. London: Faber and Faber, 1953.

18. Perloff M. 21st Century Modernism. The "New" Poetics. Oxford: Blackwell Publishers, 2002.

19. Bernstein Ch. Content's Dream Essays. 1975-84. L.A.: Sun and Moon, 1986.

20. Davidson M. From Act to Speech act // Artifice and Indeterminacy: An Anthology of New poetics / Ch. Beach (ed.) Tuscaloosa, Alabama and London: Univ. Alabama Press, 1998.

21. Heinan L. The language of inquiry. Berkeley: Univ. of California Press, 2000. P. 296-317.

22. Selected Prose of T. S. Eliot / Kermode Fr. (ed.). N.Y.: Harcourt Brace, 1975.

23. McCaffery S. The cheat of words, Toronto: ECW Press, 1996.

24. Wittgenstein L. Culture and value / transl. by P. Winch; G. H. Wright, H. Nyman (ed.), Chicago: Univ. of Chicago Press, 1980.

25. Whitman W. Starting from Paumanok // Leaves of Grass. N.Y.: New American Library, 2005. P. 11-22.

26. Смирнов И. П. Психодиахронологика. Психоистория русской литературы от романтизма до наших дней. М.: Новое лит. обозрение, 1994.

27. Judith Cofer Ortiz. The Latin Deli: An Ars Poetica. URL: https://www.slideserve.com/homer/presidingover-a-formica-counter-plastic-mother-and-child-magnetized (дата обращения: 19.12.2019).

\section{Информация об авторах.}

Щербак Нина Феликсовна - кандидат филологических наук (2015), доцент кафедры английской филологии и лингвокультурологии Санкт-Петербургского государственного университета, Университетская наб., д. 11, Санкт-Петербург, 199034, Россия. Автор более 150 научных публикаций, монографий и научно-популярных книг. Сфера научных интересов: современная литературоведческая теория, нарратология, когнитивная лингвистика. ORCID: https://orcid.org/0000-0001-8725-9717. E-mail: alpha-12@yandex.ru

Герус Алена Игоревна - студентка (2 курс, магистратура) кафедры английской филологии и лингвокультурологии Санкт-Петербургского государственного университета, Университетская наб., д. 11, Санкт-Петербург, 199034, Россия. Автор нескольких научных публикаций. Сфера научных интересов: прагмалингвистика, нарратология, когнитивная лингвистика. E-mail: aleneguere@gmail.com 